\title{
Interest Alignment Model in the Higher Education System
}

\author{
S.I. Ashmarina ${ }^{1, *}$, E.A. Kandrashina ${ }^{1}$ and I.A. Plaksina ${ }^{1}$ \\ *Corresponding author: asisamara@mail.ru \\ ${ }^{1}$ Samara State University of Economics, Samara, Russia
}

\begin{abstract}
In the modern economy, the effective development of the higher education system becomes impossible without interest alignment of universities and their stakeholders. The purpose of the study is to determine the groups of stakeholders of the higher education system according to the degree of interdependence and develop an interest alignment model, reflecting the ways of interest alignment among the selected groups of stakeholders, taking into account the impact of market and administrative mechanisms. To achieve the purpose of the study, the authors use analysis methods (when determining the set of stakeholders of the higher education system and determining the mutual interests of universities and their stakeholders), grouping (when identifying stakeholder groups according to the degree of interdependence), and developing managerial models (when developing a model for interest alignment in the higher education system). The proposed interest alignment model in the higher education system can be an effective managerial tool in shaping interrelationships of universities with stakeholders.
\end{abstract}

Keywords: administrative mechanism, higher education, interests, interest alignment model, market mechanism, stakeholders.

\section{Introduction}

Under current conditions, the sustainable development of any economic entity is determined by the ability to build mutually beneficial cooperation with numerous stakeholders. The term "stakeholder" was first introduced by E. Freeman in 1984: “A stakeholder is a group (individual) that can impact the achievement of the organization's goals or the work of the organization as a whole" [1]. Stakeholders are considered "as a single contradictory whole, the resultant of the interests of parts which will determine the organization's development" [2]. The higher education system covers a wide range of direct participants and contact audiences with not only different interests, but also different opportunities to ensure their implementation, which necessitates studying the interests of higher education stakeholders and developing an interest alignment model of interacting parties.

\section{Problem Statement}

Taking into account the fact that the interests of any economic entity are contradictory in nature, the desire to satisfy these interests leads to conflicts that can worsen the situation of other economic entities. The solution of this problem requires economic interest alignment of the subjects of interaction. Economic interest alignment means achieving a state in which each participant in interaction achieves an equilibrium state according to selected criteria [3]. A university is an integrated organization surrounded by a large number of different stakeholders, and, therefore, one of the most important areas of its activity should be to create maximum value for its stakeholders [4]. Stakeholders of universities have different needs or expectations regarding the quality of higher education [5]. Thus, to build partnerships, universities must take into account the diverse interests of their stakeholders. However, since different groups of stakeholders have a different degree of impact on the development of the higher education system, then we need to select those groups that are the most important, and determine the ways of interest alignment for each group of stakeholders.

\section{Research Questions}

The study considers the following research questions:

1) Which stakeholders have the greatest impact on the development of the higher education system? How can we group these stakeholders?

2) What are the mutual interests of universities and their stakeholders?

3) How should an interest alignment model look like in the higher education system?

4) How do market and administrative mechanisms affect the ways to harmonize interests in the higher education system? 


\section{Purpose of the Study}

The purpose of the study is to identify the groups of stakeholders of the higher education system according to the degree of interdependence and develop an interest alignment model, reflecting the ways of interest alignment by groups of stakeholders, taking into account the impact of market and administrative mechanisms.

\section{Research Methods}

The methodological basis of the research is fundamental works on the theory of stakeholders and the theory of interests. To achieve the purpose of the study, the main methods were used: analysis (to identify a set of stakeholders of the higher education system, to determine the interests of universities and their stakeholders), grouping (to highlight groups of main stakeholders of the higher education system), and the method of developing management models (higher education).

\section{Findings}

\subsection{The main stakeholder groups of the higher education system, the interests of universities and stakeholders}

To identify the most significant (important) stakeholders of the higher education system, whose interests are subject to alignment in the first place, the authors used Aubrey L. Mendelow model [6], which reflected two criteria:

- "Power": the degree of impact (high / low) on the activities of the university. The government characterizes the ability of the stakeholder to obtain the desired result from the university based on coercive instruments, financial instruments or emotional resources;

- "Interest": the level of interest (high / low) in the results of the university. Interest characterizes the needs of stakeholders and their dependence on the results of universities, as well as the desire of stakeholders to affect the university. According to [7], three factors contribute to the development of interest: knowledge, positive emotions, and personal value.

In accordance with this model, the integral indicator of the importance of the stakeholder can be determined by the formula:

Importance $=$ Power $*$ Interest

The distribution of stakeholders in the higher education system in accordance with Aubrey L. Mendelow model is presented in Fig. 1.

Degree of impact

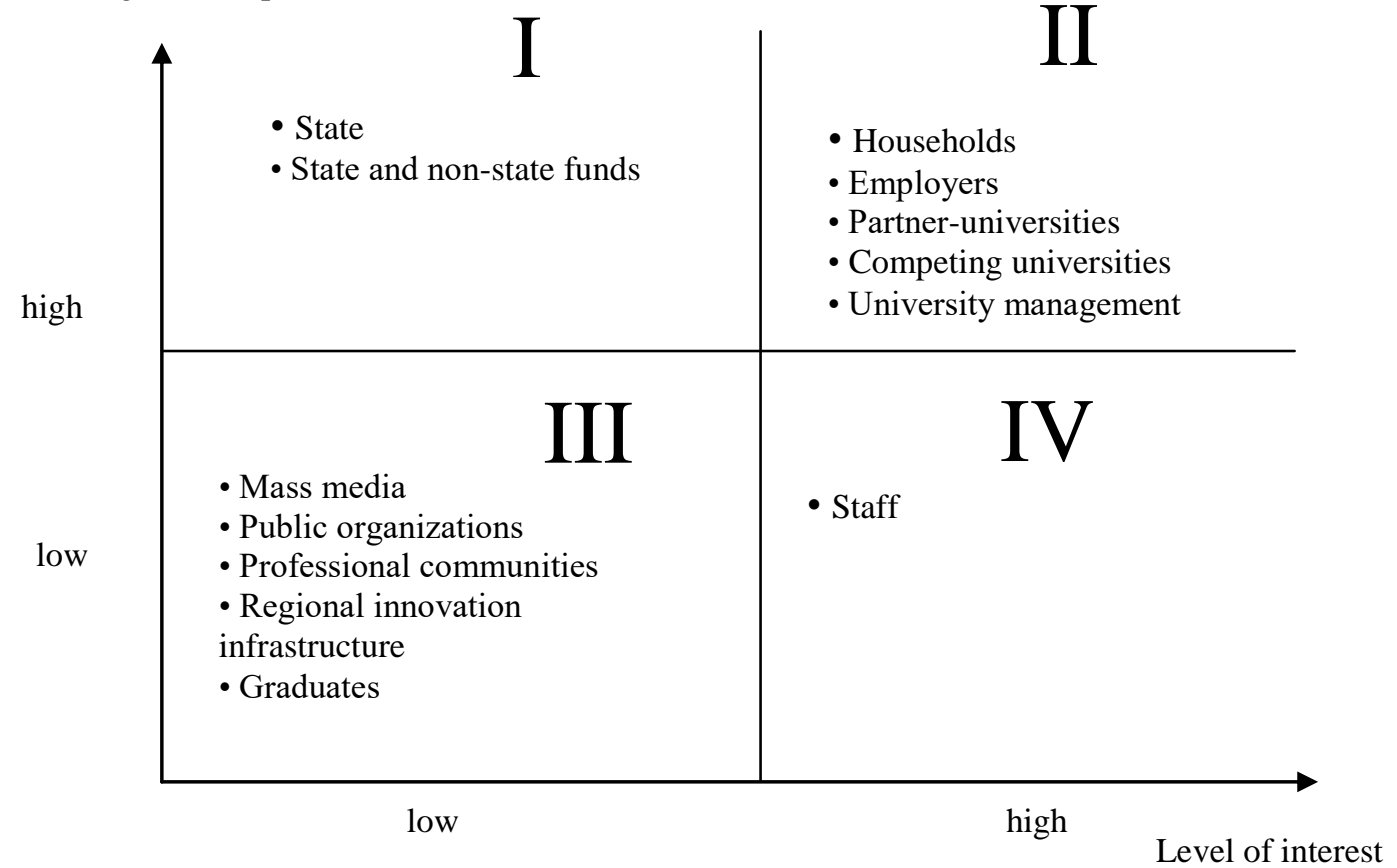

Figure 1. Distribution of university stakeholders by degree of impact and level of interest in accordance with Mendelow interdependence model (Source: compiled by the authors). 
Analysis of Fig. 1 indicates the distribution of the stakeholders of the higher education system in four quadrants according to a level of interest and degree of impact:

Quadrant I: stakeholders with a high degree of impact and low interest.

Quadrant II: stakeholders with a high degree of impact and high interest.

Quadrant III: stakeholders with a low degree of impact and a low level of interest,

Quadrant IV: stakeholders with a low degree of impact and a high level of interest.

Quadrant I includes the following stakeholders:

- A state that is a founder (for most Russian (state) universities) and a controlling body (for all universities) and, accordingly, has a strong impact on the activities of higher education institutions (through budget financing mechanisms, licensing and accreditation procedures). At the same time, the level of interest of the state in relation to universities should be recognized as low, since the state is only interested in the universities' compliance with legislation and it is not dependent on the results of universities' activities;

- State and non-state funds supporting scientific, technical and innovation activities: they have a strong impact on universities' activities through financial instruments (the grant support system) and they are not directly interested in the results of universities' activities.

Quadrant II includes:

- Households (applicants and their parents) have a strong impact on universities' activities through financial instruments (payment for educational services, which becomes the main source of funding for universities under conditions of budget cuts by the state). At the same time, households are highly dependent on universities' activities (interested in a high quality of the educational process);

- Employers have a strong impact on universities' activities through financial instruments (payment for educational services, $\mathrm{R} \& \mathrm{D}$ results) and emotional resources (recruitment of graduates) and they are highly dependent on the results of universities' activities (interested in the quality of educational services, R \& D, highly qualified specialists );

- Partner universities have an impact on universities' activities mainly through financial instruments and emotional resources (as part of joint educational, innovative and other projects) and they are highly dependent on the results of interaction. It is worth noting that a strong impact and high interest are observed, as a rule, only in the field of networking of universities;

- Competing universities have a strong impact on universities' activities through financial instruments (competition for budget financing, household funds, employers) and thus they are interested in negative results of universities' activities (unlike other groups of stakeholders, competing universities are not interested in the results of universities' activities);

- University management has a strong impact on university's activities through coercive tools (forms management policy) and has a high interest in the results of the university's activities (increase in budget and extra-budgetary funding, compliance with legal requirements, business reputation of the university). According to [8], the expectations of the university management are formed relatively: an increase in the number of students, global ratings, the number of published scientific works, the quality of research, infrastructure development, educational standards, the accreditation process, etc.

Quadrant III includes: mass media, public organizations, professional communities, regional innovation infrastructure (business incubators, etc.), graduates, and secondary schools. These groups of stakeholders are characterized by a low degree of impact (mainly through emotional resources) and a low level of interest (they do not directly depend on the results of universities' activities).

Quadrant IV includes university staff (faculty and other categories of staff) who have a high interest in the results of the university's activities (interested in decent pay and working conditions, stable functioning of the university), but they have practically no impact tools.

In order to develop the interest alignment model in the higher education system, stakeholders distributed across quadrants should be grouped according to the degree of interdependence with universities, because the stronger the dependence of the parties on each other, the stronger should be their interest alignment. Taking into account this criterion, all stakeholders of the higher education system were divided into 3 groups:

1) Stakeholders with a high degree of interdependence (Quadrant II), which have a high degree of interest in the results of the university's activities, and at the same time a high degree of impact on the interests of the university: households (applicants and their parents), employers, partner universities, competing universities and university management;

2) Stakeholders with an average degree of interdependence (Quadrants I and IV): these are stakeholders who strongly depend on the university (employees) and the university depends on them (state, state and non-state funds);

3) Stakeholders with a low degree of interdependence (Quadrant III), who have little interest in the results of the university's activities and whose impact on the interests of the university are minimal (media, public organizations, professional communities, regional innovation infrastructure, graduates, secondary schools).

Based on the grouping of stakeholders according to the degree of interdependence, the main mutual interests of universities and stakeholders were identified (Table 1). 
Table 1. Interests of universities and their stakeholders

\begin{tabular}{|c|c|c|}
\hline Stakeholder & Interests of the stakeholder & Interests of the university \\
\hline \multicolumn{3}{|c|}{ 1. Stakeholders with a high degree of interdependence } \\
\hline \multirow[t]{3}{*}{ Households } & Free higher education & Extra-budgetary funding \\
\hline & High quality educational services & $\begin{array}{l}\text { Applicants with high Unified State } \\
\text { Exam scores }\end{array}$ \\
\hline & Successful employment & Successful employment of graduates \\
\hline \multirow[t]{3}{*}{ Employers } & High quality educational services & $\begin{array}{l}\text { Extra-budgetary funding from the } \\
\text { provision of educational services }\end{array}$ \\
\hline & High quality R \& D & $\begin{array}{l}\text { Extra-budgetary funding from } \mathrm{R} \& \\
\mathrm{D}\end{array}$ \\
\hline & Highly qualified graduates & Successful employment of graduates \\
\hline Partner universities & \multicolumn{2}{|c|}{ Joint implementation of educational, research and other projects } \\
\hline $\begin{array}{l}\text { Competing } \\
\text { universities }\end{array}$ & \multicolumn{2}{|c|}{$\begin{array}{l}\text { Budgetary and extra-budgetary funding with negative results of a competing } \\
\text { institution }\end{array}$} \\
\hline \multirow[t]{3}{*}{$\begin{array}{l}\text { University } \\
\text { management }\end{array}$} & $\begin{array}{l}\text { Budgetary and extra-budgetary } \\
\text { funding }\end{array}$ & \multirow[t]{3}{*}{$\begin{array}{l}\text { Highly qualified management team } \\
\text { and effective management policies }\end{array}$} \\
\hline & Compliance with legal requirements & \\
\hline & $\begin{array}{l}\text { Strengthening the business } \\
\text { reputation of the university }\end{array}$ & \\
\hline \multicolumn{3}{|c|}{ 2. Stakeholders with an average degree of interdependence } \\
\hline \multirow[t]{2}{*}{ State } & - & Budget financing \\
\hline & $\begin{array}{l}\text { Compliance with legal requirements } \\
\text { and public policy }\end{array}$ & $\begin{array}{l}\text { Compliance with legal requirements } \\
\text { and public policy }\end{array}$ \\
\hline $\begin{array}{l}\text { State and non-state } \\
\text { funds }\end{array}$ & - & $\begin{array}{l}\text { Extra-budgetary funding in the form } \\
\text { of grants }\end{array}$ \\
\hline \multirow[t]{3}{*}{ Staff } & Decent pay & \multirow[t]{3}{*}{ Highly qualified specialists } \\
\hline & Favorable working conditions & \\
\hline & Sustainable university activity & \\
\hline \multicolumn{3}{|c|}{ 3. Stakeholders with a low degree of interdependence } \\
\hline $\begin{array}{l}\text { Mass media, public } \\
\text { organizations, } \\
\text { professional } \\
\text { communities }\end{array}$ & $\begin{array}{l}\text { Training of highly qualified } \\
\text { personnel }\end{array}$ & - \\
\hline $\begin{array}{l}\text { Regional innovation } \\
\text { infrastructure }\end{array}$ & - & Using infrastructure \\
\hline Graduates & - & $\begin{array}{l}\text { Raising funds to the endowment } \\
\text { fund }\end{array}$ \\
\hline Secondary schools & - & Attracting applicants \\
\hline
\end{tabular}

Source: compiled by the authors.

\subsection{Interest alignment model in the higher education system}

When developing the interest alignment model in the higher education system, the following aspects were taken into account:

1) Ways to harmonize interests;

2) Stakeholder groups according to the degree of interdependence;

3) Market and administrative mechanisms of interaction of subjects in the higher education system.

When choosing the ways to align interests, the authors used an approach formed by psychologists K. Thomas and R. Kilman in relation to interaction in conflict situations [9], according to which five strategies of interaction between conflicting parties are outlined: competition, cooperation, compromise, avoidance and adaptation.

The choice of applying a specific method of interest alignment is determined by the degree of interdependence and interconnectedness of subjects of economic relations (the stronger the dependence of subjects on each other, the higher the degree of realization and their interest alignment).

Based on the previously identified groups of stakeholders according to the degree of interdependence with universities, and taking into account the strategies of interaction between the conflicting parties, proposed by $\mathrm{K}$. Thomas and R. Kilman, the authors developed a model to align the interests of the university and its stakeholders (Fig. 2).

Analysis of the matrix model shown in Fig. 2, allows us to conclude on the following distribution methods for interest alignment among the stakeholder groups:

- Stakeholders with a high degree of interdependence, it is advisable to use the methods of "Cooperation" and "Compromise";

- Stakeholders with an average degree of interdependence, it is advisable to use "Adaptation", "Competition" and "Compromise";

- Stakeholders with a low degree of interdependence, it is advisable to use "Avoidance". 
When selecting the methods to align the interests of the university with its stakeholders, taking into account the degree of interdependence of stakeholders, the authors took into account the impact of market and administrative mechanisms on harmonizing interests.

The influence of the market mechanism on the harmonization of the interests of the university and its stakeholders is observed in interactions that are formed in the relevant markets: the market for educational services (interaction "university-households", "university-employers", "university-university"); the market of scientific and technical products (interaction "university - employers"); labor market (interaction "university - employers", "university university," "university - employees").

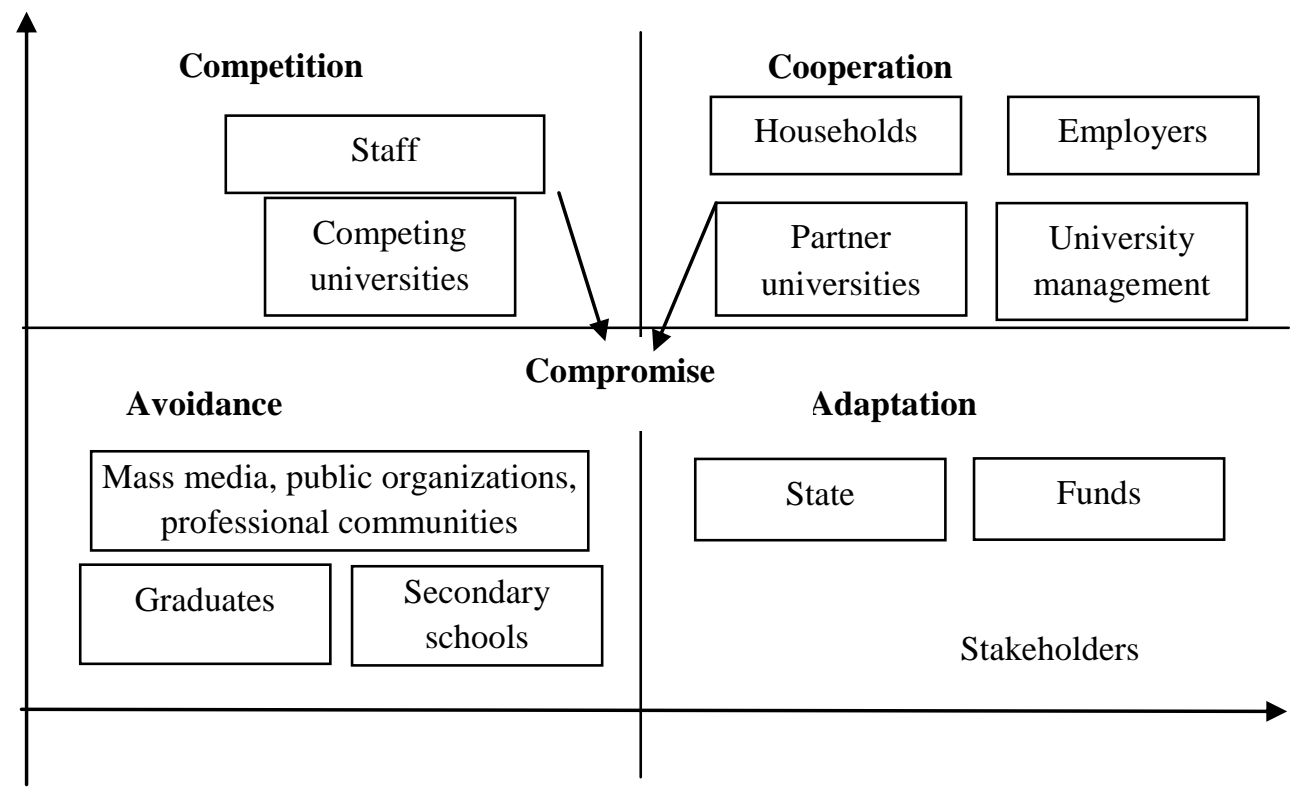

Figure 2. The interest alignment model in the higher education system (Source: compiled by the authors).

Along with the market mechanism, the administrative mechanism has a special impact on interest alignment of the university and its stakeholders, which is implemented through the factor of budget (state) financing of educational, research activities of universities.

In order to realize the interests of both parties with regard to high-level stakeholders with a high degree of interdependence, it is advisable to apply the "Cooperation" interest alignment method, in which the interests of each of the parties are fully satisfied. At the same time, it is obvious that not always and not all the interests of interacting parties can be satisfied without harming the interests of the other party, therefore, in some cases, the "Compromise" method (balance of interests) can be used.

For example, in relation to the Russian practice, in the "University - Households" chain each applicant is interested in receiving free (budget) higher education, and the university - in raising extra-budgetary funding from households. Therefore, it is advisable to achieve a compromise (balance of interests): for applicants with high Unified State Exam scores, interests in obtaining budgetary higher education are satisfied (to the detriment of the interests of the university), but the interests of other applicants (entering the university on a fee basis) remain disadvantaged when meeting the interests of the university. Accordingly, a compromise as a way of interest alignment serves as a basis for interaction of the university and households. Further interest alignment of the parties is possible through cooperation. Cooperation is the preparation of highly qualified personnel and their further successful employment (both parties are interested), for which the university provides a high quality educational process, and households (applicants, and later - students) conscientious training.

In the "University-Employers" chain, the interests of the parties coincide as much as possible (correspond to each other), and therefore interest alignment is possible and expedient through cooperation, which consists in providing employers with free high-quality results (products) of universities' activities (educational services, R \& D results, graduates ).

As for "University - University" chain, two types of interactions are formed: interaction of competing universities and interaction of partner universities.

The first kind of interaction is not obvious: competing universities do not directly interact with each other, but in the struggle for financial resources (budget financing, funds, households, employers) influence each other's interests: universities that compete with each other are interested in own raising resources and they are not interested if competitors raise such resources. Such diametrically opposite interests, in our opinion, are not subject to alignment.

The second type of interaction is formed, as a rule, within the framework of network interaction, when universities participate in the implementation of joint projects and their interests coincide. In this case, interests can be aligned through cooperation. Cooperation of universities in the framework of network interaction determines the need to find new forms of relationships, which leads to initiative changes in universities' activities. 
In the "University - Management" chain, the interests of the parties coincide as much as possible (ensuring the sustainable development of the university) and can be aligned through cooperation. Thus, interest alignment of universities with the interests of the most important stakeholders (with a high degree of interdependence) is advisable to carry out through cooperation. In relation to university stakeholders with an average degree of interdependence, adaptation or coercion can be used to align interests. Of particular note is the impact of the administrative mechanism on the relationship of the university with the state and state funds.

Thus, in the "University - State" chain, each university is interested in obtaining the maximum amount of budget financing, while the state is interested in supporting only effective (in accordance with the criteria established by state policy) universities. Accordingly, with this interaction, the state has the opportunity to fully realize its interests (since it sets the "rules of the game" itself), and universities only have the opportunity to adapt to the requirements set by the state. In this case, the only possible way to harmonize the interests is adaptation.

Similarly, in the "University-State and Non-State Funds" chain, each university is interested in raising funding in the form of grant support, while the funds are interested in providing funding for the most promising research, innovation, and other projects. Accordingly, within the framework of this interaction, foundations fully realize their interests, and universities adapt to their requirements.

In the "University - Employees" chain, the common interests of the subjects of interaction is manifested in the fact that they all strive to maintain the effective functioning of the university as an organization, while receiving some benefit from their actions. The university as an employer is interested in attracting highly qualified specialists, and employees are interested in working conditions (including payment). Within the framework of such interaction, the institution of higher education realizes its interests as fully as possible, since it defines the conditions ("rules of the game") which employees accept, which predetermines the use of this method of interest alignment, like coercion. However, it is obvious that under conditions of tough competition in the labor market, coercion cannot be an effective way of interest alignment of the employer and employees. Therefore, the most expedient approach is to achieve a compromise (balance of interests) in which each of the parties makes concessions to the other party (employees accept working conditions and perform their work efficiently, the university as an employer establishes the most favorable working conditions).

As a rule, interest alignment does not occur for university stakeholders with a low degree of interdependence. There is a deviation from interest alignment, which is due to a low interest of the parties in results of each other (this applies interaction of universities with media, public organizations, professional communities) or the ability of one of the parties to satisfy their interests outside of this interaction (for example, secondary schools can enter interaction with other universities).

\section{Conclusion}

According to the results of the study, the main stakeholder groups of the higher education system are formed according to the degree of interdependence with universities. The authors suggest their interest alignment model in the higher education system, reflecting the ways aligning the interests in relation to selected groups of stakeholders, taking into account market and administrative mechanisms. The proposed model can be an effective tool for making management decisions in the higher education system when aligning interests of interacting actors.

\section{References}

1. R.E. Freeman, Strategic management: A stakeholder approach. New York, NY: Harpercollins College Div (1984).

2. M.Yu. Sheresheva, M.M. Palt, Coordination of stakeholders' interests in network inter-company interaction. Vestnik of the Immanuel Kant Baltic Federal University. The Humanities and Social Sciences Series, 3, 17-23. Retrieved from https://journals.kantiana.ru/upload/iblock/e27/Shersheva\%20M.,\%20Palt\%20M._17-23.pdf. Accessed: 08.01.2019 (2014). [in Rus.].

3. V.Ya. Okrushko, Problems of managing economic interests. The Problems of Modern Economics, 1(41), $62-66$. Retrieved from https://cyberleninka.ru/article/v/problemy-upravleniya-ekonomicheskimi-interesami (2012). [in Rus.].

4. R. Labanauskis, R.Givenicius, Role of stakeholder leading to development of higher education services. Engineering Management in Production and Services, 9(3), 63-75. DOI: 10.1515/emj-2017-0026 (2017).

5. H.T. Pham, L. Starkey, Perceptions of higher education quality at three universities in Vietnam. Quality Assurance in Education, 24(3), 363-369. DOI: 10.1108/QAE-07-2014-0037 (2016).

6. A. Mendelow, Stakeholder mapping. In Jack Rockart (Ed.), Proceedings of the 2nd International Conference on Information Systems, (pp. 246-250), Cambridge, MA: Association for Computing Machinery (1981).

7. S. Hidi, K.A. Renninger, The four-phase model of interest development. Educational Psychologist, 41(2), 111-127. DOI: $10.1207 / \mathrm{s} 15326985$ ep4102_4 (2006).

8. M.V. Sunder, Lean six sigma in higher education institutions. International Journal of Quality and Service Sciences, 8(2), 159-178. DOI: 10.1108/IJQSS-04-2015-0043 (2016).

9. K.W. Thomas, R.H. Kilmann, Thomas-Kilmann conflict mode instrument profile and interpretive report (Xicom, Incorporated). Profile and interpretive report. Retrieved from https://www.skillsone.com/Pdfs/smp248248.pdf. Accessed: 08.01.2019 (2010). 